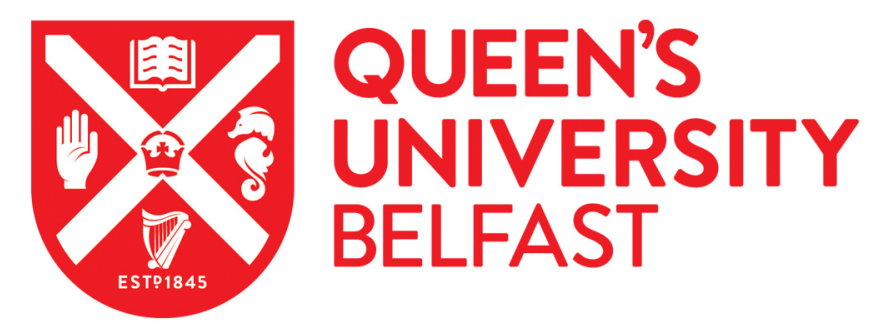

\title{
Quantifying reproductive state and predator effects on copepod motility in ephemeral ecosystems
}

Cuthbert, R., Dalu, T., Wasserman, R. J., Dick, J., Callaghan, A., Froneman, W., \& Weyl, O. (2019). Quantifying reproductive state and predator effects on copepod motility in ephemeral ecosystems. Journal of Arid Environments. https://doi.org/10.1016/j.jaridenv.2019.05.010

Published in:

Journal of Arid Environments

Document Version:

Peer reviewed version

Queen's University Belfast - Research Portal:

Link to publication record in Queen's University Belfast Research Portal

Publisher rights

Copyright 2019, Elsevier.

This work is made available online in accordance with the publisher's policies. Please refer to any applicable terms of use of the publisher.

\section{General rights}

Copyright for the publications made accessible via the Queen's University Belfast Research Portal is retained by the author(s) and / or other copyright owners and it is a condition of accessing these publications that users recognise and abide by the legal requirements associated with these rights.

Take down policy

The Research Portal is Queen's institutional repository that provides access to Queen's research output. Every effort has been made to ensure that content in the Research Portal does not infringe any person's rights, or applicable UK laws. If you discover content in the Research Portal that you believe breaches copyright or violates any law, please contact openaccess@qub.ac.uk. 


\section{Quantifying reproductive state and predator effects on copepod motility in}

\section{3 ephemeral ecosystems}

4 Ross N. Cuthbert ${ }^{* 1,2,3}$, Tatenda Dalu ${ }^{4,5}$, Ryan J. Wasserman ${ }^{6,5}$, Jaimie T.A. Dick ${ }^{1}$, Amanda

$5 \quad$ Callaghan $^{3}$ P. William Froneman ${ }^{7}$, Olaf L.F. Weyl ${ }^{2}$

$6 \quad{ }^{1}$ Institute for Global Food Security, School of Biological Sciences, Queen's University

7 Belfast, Medical Biology Centre, Belfast BT9 7BL, Northern Ireland

$8 \quad{ }^{2}$ DST/NRF Research Chair in Inland Fisheries and Freshwater Ecology, South African

9 Institute for Aquatic Biodiversity (SAIAB), Grahamstown 6140, South Africa

$10{ }^{3}$ Ecology and Evolutionary Biology, School of Biological Sciences, University of Reading,

11 Harborne Building, Reading RG6 6AS, England

$12{ }^{4}$ Department of Ecology and Resource Management, University of Venda, Thohoyandou 13 0950, South Africa

$14{ }^{5}$ South African Institute for Aquatic Biodiversity (SAIAB), Grahamstown 6140, South Africa

${ }^{6}$ Department of Biological Sciences and Biotechnology, Botswana International University of

16 Science and Technology, Palapye, Botswana

$17{ }^{7}$ Department of Zoology and Entomology, Rhodes University, Grahamstown 6140, South

18 Africa

*Corresponding author: e-mail, rcuthbert03@qub.ac.uk; orcid ID, https://orcid.org/0000- 


\section{Abstract}

Ephemeral wetlands in arid environments are unique ecosystems with atypical trophic structuring, often dominated by invertebrate predation. Copepod behavioural traits and vulnerabilities to predation can vary substantially according to reproductive status. Gravid female copepods may be more vulnerable to predation due to reduced escape speeds or higher visibility for predators. Here, we quantify how reproductive status modulates horizontal motility rates of the predatory ephemeral pond specialist copepod Lovenula raynerae, and the responsiveness of the copepod to predator cues of the notonectid Anisops debilis. Males exhibited significantly higher motility rates than gravid female copepods, however chemical predator cues did not significantly influence activity rates in either sex. The lack of responsiveness to predator cues by specialist copepods in ephemeral wetlands may result from a lack of predation pressure in these systems, or due to time stress to reproduce during short hydroperiods. In turn, this could increase predation risk of copepods from externallyrecruited top predators in ephemeral wetlands, and potentially contribute to the development of skewed sex ratios in favour of females.

\section{Keywords}

Lovenula raynerae; notonectid; hydroperiod; trait-mediated responses; temporary ponds; sexskewed populations 
Ephemeral wetland ecosystems remain poorly studied due to high spatial and temporal heterogeneity, and function fundamentally differently from permanent waters (see Dalu et al. 2017a). In arid environments, ephemeral aquatic ecosystems provide particularly important aquatic habitat patches for rare and endemic species (De Meester et al. 2005). Population demographics are known to vary profoundly over the hydroperiod in ephemeral wetlands (Wasserman et al. 2018; Cuthbert et al. 2019), and such variations can have marked implications for population success (Kiørboe 2006). In copepods, for example, predation pressure may not be equally shared by the sexes. Gravid female copepods may be more vulnerable to predation pressure as they are less agile and more conspicuous to predators (Maier 1995, Svensson 1997, Mahjoub et al. 2011). Behavioural examinations of copepods have, however, thus far focused on permanent aquatic ecosystems.

Ephemeral aquatic ecosystems exhibit atypical trophic structuring, where characteristically shallow food webs enable copepods to occupy high trophic levels (Dalu et al. 2017b). Predation risks are alleviated in these wetlands for some of the hydroperiod as many species are internally recruited (e.g. Wasserman et al. 2016), with higher order hexapod predation pressure (e.g. notonectids) arriving later (O’Neill and Thorp 2014, Wasserman et al. 2018). Generally, within aquatic systems, the prevalence of higher-order predatory cues profoundly affects invertebrate behaviour, for instance by reducing activity rates (Paterson et al. 2013; Alexander et al. 2013). Examinations of these trends are, however, lacking in ephemeral ecosystems where predation pressures are transient (Wasserman et al. 2018; but see Brendonck et al. 2002; De Roeck et al. 2005).

Here, we examine variabilities in motility rates according to reproductive status in the atypically large $(4.0-5.0 \mathrm{~mm})$ and predatory ephemeral pond specialist copepod Lovenula raynerae Suárez-Morales, Wasserman, Dalu (Suárez-Morales et al. 2015) under the presence of different predator cue treatments. We were particularly interested in differences between 
gravid and non-gravid copepods regarding invertebrate predation risk. Invertebrate predators, such as notonectids, utilise movement (visual) and hydromechanical cues for prey detection (e.g. Diéguez and Gilbert 2003). Responses of prey to predation threat may, therefore, involve a decrease in activity to avoid detection (passive avoidance), or an increase of activity for active avoidance. We hypothesised that males would exhibit active avoidance strategies, while gravid females would employ passive avoidance strategies, given the reduced mobility potential associated with the carrying of an egg-load of the latter.

Adult $L$. raynerae were sampled from an ephemeral wetland $\left(33^{\circ} 10^{\prime} 04.1^{\prime \prime S}\right.$ $\left.27^{\circ} 16^{\prime} 10.6^{\prime \prime E}\right)$ in the Eastern Cape, South Africa using a $64 \mu \mathrm{m}$ zooplankton net of $30 \mathrm{~cm}$ diameter. Copepods were transported to a laboratory with a controlled environment (CE) at Rhodes University, Grahamstown, where adult males and females $(4.5-5.0 \mathrm{~mm})$ were housed at $25 \pm 1^{\circ} \mathrm{C}$ in $25 \mathrm{~L}$ tanks containing source pond water under a 14:10 light:dark photoperiod. Adults of the notonectid Anisops debilis Gersaeker $(6.92 \pm 0.04 \mathrm{~mm})$ were collected by towing

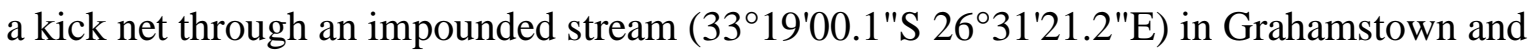
maintained in the same CE room. Culex pipiens sensu lato were collected from containerstyle habitats on the Rhodes University campus.

To derive the effects of sex and predator cues on copepod motility, we employed a $2 \times 2$ experimental design with respect to sex (two levels) and predator cues (two levels). Only male and/or gravid female copepods were used for the study. Non-gravid females were, however, not employed as their reproductive (egg-production) state was difficult to determine and could have implications for behavioural performance. Adult male and gravid female $L$. rayerae were fed on a diet of $C$. pipiens larvae for $72 \mathrm{~h}$ prior to use. To create chemical predator cues for experimental use, A. debilis were maintained in $2 \mathrm{~L}$ aquaria of $16.5 \mathrm{~cm}$ diameter at a stocking density of 7.5ind. $\mathrm{L}^{-1}$ and fed ad libitum on a standard diet of $C$. pipiens larvae. After $48 \mathrm{~h}$ of cue accumulation, water was extracted and strained through 
$200 \mu \mathrm{m}$ mesh for immediate use in the experiment. Control water was maintained in identical conditions, but in the absence of notonectid predators (i.e. $2 \mathrm{~L}$ aquaria for $48 \mathrm{~h}$ ). Male and/or gravid female copepods were then added to jars of $5.6 \mathrm{~cm}$ diameter, with a line marked across the middle of the bottom of the arena, containing $25 \mathrm{~mL}$ of water of the allocated cue treatment, and allowed to settle for $20 \mathrm{~min}$ ( $n=12$ per experimental group). After this acclimation period, the number of line crosses was visually recorded over a 5 min observation period. Lighting was positioned directly above arenas at an intensity of 930 lux.

Using the R environment, the effects of 'sex' and 'predator cue' on the number of line crosses exhibited were analysed using generalised linear models (GLMs) assuming a quasiPoisson distribution as residuals were overdispersed. Non-significant terms and interactions were removed stepwise to maximise parsimony (Crawley, 2007).

Males exhibited an average of $22.54( \pm$ SE: \pm 1.55$)$ line crosses, whilst gravid females exhibited 13.04 ( \pm SE: \pm 2.13$)$. Overall, male L. raynerae exhibited significantly greater motility than gravid females $\left(F_{(1,46)}=11.28, \mathrm{p}=0.002\right.$; Fig. 1$)$. The presence of predator cues had no effect on copepod motility $\left(F_{(1,45)}=1.07, \mathrm{p}=0.31\right)$. There was no significant 'sex $\times$ predator cue' interaction effect $\left(F_{(1,44)}=0.52, \mathrm{p}=0.47\right)$, indicating that the lack of predator cue effects on motility was consistent between copepod sexes.

The ephemeral pond-specialist copepod L. raynerae does not appear to use alternative anti-predation strategies, with respect to motility, based on reproductive state. Neither males nor females were responsive to the presence of predator cues from notonectids in terms of their horizontal motility levels. No significant increase or decrease in motility was detectable. Males were, however, more active than the gravid females irrespective of the predation cue treatment. A number of invertebrates have shown high responsiveness to predator cues (e.g. Paterson et al. 2013; Weiss et al. 2015) and even to conspecific alarm cues associated with 
predation (Wasserman et al. 2014). It is plausible that the necessity of high resource acquisition for reproduction, compounded by time pressures associated with characteristically short hydroperiods in arid environments, may negate anti-predator responses of $L$. raynerae. Alternatively, these copepods may respond to conspecific alarm cues rather than predator cues; however, this was not tested in the study. Furthermore, the effects of predator cues on vertical migration strategies in copepods, alongside other anti-predator mechanisms, requires further investigation in heterogenous aquatic environments. Nevertheless, the lack of motility response to predation, coupled with consistently higher activity levels of males, may further increase the susceptibility of male copepods to predation by invertebrates such a notonectids, potentially further accentuating the development of female-skewed ratios which have been shown to arise in wild L. raynerae populations in ephemeral ponds (Wasserman et al. 2018). Thus, these traits may further contribute to the development of sex-skewed demographics within ephemeral ecosystems.

\section{Acknowledgements}

This study forms part of a PhD studentship funded by the Department for the Economy, Northern Ireland. We extend gratitude to Rhodes University for the provision of laboratory facilities. We acknowledge use of infrastructure and equipment provided by the SAIAB Research Platform and the funding channelled through the NRF-SAIAB Institutional Support system. This study was partially funded by the National Research Foundation - South African Research Chairs Initiative of the Department of Science and Technology (Inland Fisheries and Freshwater Ecology, Grant No. 110507).

\section{References}


Alexander, M. E., Dick, J. T. A. and O’Connor, N. E. (2013) Born to kill: Predatory functional responses of the littoral amphipod Echinogammarus marinus Leach throughout its life history. J. Exp. Mar. Biol. Ecol. 439, 92-99.

Brendonck, L., Michels, E., De Meester, L. and Riddoch, B. (2002) Temporary pools are not 'enemy-free'. Hydrobiologia 486, 147-159.

Crawley, M. J. (2007) The R book. John Wiley \& Sons, Chichester.

Cuthbert, R. N., Dalu, T., Wasserman, R. J., Weyl, O. L. F., Callaghan, A., Froneman, P. W., Dick, J. T. A. (2019) Sex-skewed trophic impacts in ephemeral wetlands. Freshw. Biol. 64, 359-366.

Dalu, T., Wasserman, R. J. and Dalu, M. T. B. (2017a) Agricultural intensification and drought frequency increases may have landscape level consequences for ephemeral ecosystems. Glob. Chang. Biol. 23, 983-985.

Dalu, T., Wasserman, R. J., Froneman, P. W. and Weyl, O. L. F. (2017b) Trophic isotopic carbon variation increases with pond's hydroperiod: Evidence from an Austral ephemeral ecosystem. Sci. Rep. 7, 7572.

De Roeck, E. R. M., Artois, T. and Brendonck, L. (2005) Consumptive and non-consumptive effects of turbellarian (Mesostoma sp.) predation on anostracans. Hydrobiologia 542, $103-111$.

De Meester, L., Declerck, S., Stoks, R., Louette, G., Van De Meutter, F., De Bie, T., Michels, E and Brendonck, L. (2005) Ponds and pools as model systems in conservation biology, ecology and evolutionary biology. Aquat. Cons. Mar. Freshw. Ecosyst. 15, $715-725$. 
Diéguez, M. C. and Gilbert, J. J. (2003) Predation by Buenoa macrotibialis (Insecta, Hemiptera) on zooplankton: effect of light on selection and consumption of prey. $J$. Plankt. Res. 25, 759-769.

Kiørboe, T. (2006) Sex, sex-ratios, and the dynamics of pelagic copepod populations. Oecologia, 148, 40-50.

Mahjoub, M. S., Souissi, S., Michalec, F. G., Schmitt, F. G. and Hwang, J. S. (2011) Swimming kinematics of Eurytemora affinis (Copepoda, Calanoida) reproductive stages and differential vulnerability to predation of larval Dicentrarchus labrax (Teleostei, Perciformes). J. Plankt. Res. 33, 1095-1103.

Maier, G. (1995) Mating frequency and interspecific matings in some freshwater cyclopoid copepods. Oecologia 101, 245-250.

O’Neill, B. J. and Thorp, J. H. (2014) Untangling food-web structure in an ephemeral ecosystem. Freshwater Biol. 59, 1462-1473.

Paterson, R. A., Pritchard, D. W., Dick, J. T. A., Alexander, M. E., Hatcher, M. J. and Dunn, A. M. (2013) Predator cue studies reveal strong trait-mediated effects in communities despite variation in experimental designs. Anim. Behav., 86, 1301-1313.

Suárez-Morales, E., Wasserman, R.J. and Dalu, T. (2015) A new species of Lovenula Schmeil (Copepoda, Calanoida, Diaptomidae) from the Eastern Cape Province of South Africa. Crustaceana, 88, 324-342.

Svensson, J. E. (1997) Fish predation on Eudiaptomus gracilis in relation to clutch size, body size, and sex: A field experiment. Hydrobiologia 344, 155-161.

Wasserman, R. J., Kramer, R., Vink, T.J.F. and Froneman, P.W. (2014) Conspecific alarm cue sensitivity by the estuarine calanoid copepod, Paracartia longipatella. Aust. Ecol. 39, 732-738. 
201

202

203

204

205

206

Wasserman, R. J., Alexander, M. E., Barrios-O’Neill, D., Weyl, O. L. F. and Dalu, T. (2016) Using functional responses to assess predator hatching phenology implications for pioneering prey in arid temporary pools. J. Plankt. Res. 38, 154-158.

Wasserman, R. J., Weston, M., Weyl, O. L. F., Froneman, P. W., Welch, R. J., Vink, T. J. F. and Dalu, T. (2018) Sacrificial males: the potential role of copulation and predation in contributing to copepod sex-skewed ratios. Oikos 127, 970-980.

Weiss, L. C., Leimann, J. and Tollrian, R. (2015) Predator-induced defences in Daphnia longicephala: location of kairomone receptors and timeline of sensitive phases to trait formation. J. Exp. Biol. 218, 2918-2926.

(1)

7

8

(1)


207 Fig. 1. Effect of sex and notonectid cues on the motility (number of line crosses) of male and 208 gravid female Lovenula raynerae. Means are + SE ( $n=12$ per experimental group). 